Joanna Jaroszyk

ORCID: https://orcid.org/0000-0003-3285-2163

Adam Mickiewicz University in Poznań, Poland

\title{
The importance of the School of Journalism of the Catholic Church in the system of the reform in Francoist Spain
}

\begin{abstract}
This article deals with the issues of educating journalists during the Franco regime in Spain and the place occupied by the School of Journalism of the Catholic Church in this system. The first years of dictatorship were characterized by a strong subordination of education and occupation to the current interests of the state, which regulated access to the profession and education only within the framework of the State School of Journalism. In the second half of the 50's there was a gradual liberalization of the system, consisting in the gradual admission of other entities to the organization of vocational education of journalists, especially the Catholic Church. This allowed for the launch in 1960 of the School of Journalism of the Catholic Church, the functioning of which was the first manifestation of the regime's gradual withdrawal from state supervision over the process of educating journalists. The Catholic Church School referred to the pre-war, excellent traditions of the journalism school organized by the Catholic daily El Debate, becoming a kind of counterweight to the regime's State School of Journalism. The competition between schools (although still slight at that time) contributed to an increase in the quality of education. The emphasis on the completion of general education or the design of curricula taking into account the development of information technology made it possible to equip students with competences required in the labour market, which previously could only be obtained to a greater or lesser extent in practice.
\end{abstract}

\section{Keywords}

Franco regime, journalist education, State School of Journalism, School of Journalism of the Catholic Church. 


\section{Introduction}

The victory of General Francisco Franco's forces in April 1939, after a civil war that devastated Spain, entailed the construction of a system in which information activities were subjected to strict state control. As early as April 1938, under the conditions of the ongoing war, the Press Law was promulgated in Spain, according to which 'the organisation, custody and control of the national periodical press institution belong to the State.' This law subjected the exercise of the journalistic profession to detailed regulation, exercising control through three means, including: The Journalists' Register, the National School of Journalism and the Spanish Union of Journalists.

By setting up the National School of Journalism in Madrid in 1941, the State ensured that it had a monopoly on training for the profession, allowing only graduates of the school to practise it. This ruled out the possibility of other bodies, including the Catholic Church, which had many years of experience and merit in this field, to organise training.

The aim of this paper is not only to present, in a synthetic way, the institutional framework within which the education of journalists in Francoist Spain took place, but also to present the place of the School of Journalism of the Catholic Church within this framework. The School took over the excellent pre-war tradition of the school of journalism that was organised at the Catholic daily El Debate and became a kind of counterbalance to the regime's State owned School of Journalism. The main objective is to try to answer the question of what changes the education of journalists underwent during the Francoist period and to what extent these changes corresponded to the gradual liberalisation of the political system. These findings will in turn help to determine whether and on what terms the State's monopoly in this area was broken by allowing other entities to organise training. The question of the quality of education, subjected first to total and then to partial control by the regime, is equally important.

${ }^{1}$ This law, created with the ongoing war in mind, eventually lasted for 28 years. Gonzalo Dueñas concluded that the first 20 years of the law were so monolithic, unified and oppressive that one might as well start studying the Spanish press from 1958 onwards, see G. Dueñas, La ley de prensa de Manuel Fraga, Madrid 1969, p. 5. 


\section{Control over the journalistic profession in Francoist Spain}

As early as at the beginning of the Spanish Civil War, in addition to building administrative structures, care was taken to ensure the smooth functioning of the propaganda and information apparatus. For journalists, this meant the requirement of fidelity and adherence to the ideological principles underlying the "New State". In other words, the first actions of the authorities in this area focused on purging (depuración) the journalistic community of professionals who, for various reasons, did not meet the above criterion. This is not surprising, however, since the preamble to the 1938 Law defines the tasks of a journalist as 'an apostle of the thought and faith of the Nation, and a worthy worker in the service of Spain.' The journalist, before receiving his ID card, also had to take a specific oath, which read as follows: 'I swear before God, Spain and her Chief, to serve the Unity, Greatness and Freedom of the Fatherland, with total devotion to the principles of the National-Syndicalist State; never allowing falsehood, intrigue or ambition to distort my style of daily work. ${ }^{3}$

Originally, the mission of ideological verification of journalists was entrusted to the Association of Journalists (Asociación de Prensa), but this competence soon fell to the Ministry of Interior Affairs under the Press Law of 1938. After the end of the civil war, on 24 May 1939, a decree was issued ordering the entry into the Register of Journalists all those journalists who had been in the areas captured by Franco's forces after 31 December $1938 .{ }^{4}$ As early as April 1940, this rule was supplemented by another decree ordering the verification of all journalists, including those whose names had already been entered into the Register. ${ }^{5}$

The correctness of the procedure was supervised by a judge appointed for this purpose, who then gave his opinion on the applications submitted to the General Director of the Press, responsible for the decision on issuing a journalist card

2 J. J. Sanchez Aranda Jose, C. Barrera, Historia del periodismo espanol, Pampeluna 1992, p. 398.

M. Fernandez Areal, Consejo de Guerra. Los riesgos del Periodismo bajo Franco, Pontevedra 1997, p. 37.

${ }^{4}$ J. Terron Montero, La prensa en España durante el regimen de Franco. Un intento de analisis politico, Madryt 1981, pp. 62-63.

Orden de 24 de mayo (Ministerio de la Gobernacion) sobre depuración de la conducta de periodistas en relación con el Movimiento Nacional (Ordinance of May 24, 1939 to verify the conduct of journalists in connection with the National Movement) B.O.E. num. 145 de 25 de mayo 1939, p. 2822. 
and entering the candidate into the Official Register. A refusal to issue a card entailed a ban on practice of journalism, which was particularly harsh for persons already employed in an editorial office or news agency. The administration used this tool scrupulously, because by 1942, out of 4,000 applications, only 1,800 were granted. ${ }^{6}$ There are no data indicating how many journalists voluntarily gave up their profession, knowing that they would not pass the vetting because of their political ties with the republican government or for simply refusing to legitimise the new regime. There were undoubtedly many of them given the liquidation of many journals for political reasons, or the reduction of the volume of those that remained due to the economic crisis and rationing of printing paper. At the same time, there are known cases of journalists who were forgiven their former leftist convictions and activities by the new authorities in exchange for enthusiastic support and work to promote the values of the regime. ${ }^{7}$ Such manifestations of opportunism, occurring, probably, in all totalitarianisms and authoritarianisms, also found favour in Francoist Spain.

\section{The monopoly of the State School of Journalism}

The purge of journalists whose past or political beliefs did not guarantee loyalty to the regime was not the only measure taken by the authorities. The implementation of the ambitious intentions of the 1938 Press Law required the creation of conditions for the professional formation of journalists, corresponding to the vision of journalism as a "service" to the state and its ideology. These objectives were to be served by the creation of the State School of Journalism, which was to ensure not only the professional training of staff, but also an appropriate ideological formation.

In 1940, further training courses for journalists were launched under the auspices of the General Directorate of the Press, and the School itself opened its doors on 2 January 1942 in Madrid (the idea of locating the school within the structure of the University did not gain acceptance). From then on, graduation from the National School of Journalism became the sine qua non for obtaining

${ }^{6}$ J. Terron Montero, La prensa en España durante el regimen de Franco. Un intento de analisis politico, Madryt 1981, p. 64.

M. Cruz Seoane, M. Dolorez Sainz, Cuatro siglos de periodismo en España. De los avisos a los periódicos digitales, Madryt 2015, pp. 259-260. 
a journalist's card, without which it was impossible to engage in information activities. The candidate had to be Spanish, a high school graduate "in good conduct" and a member of the FET y JONS (Falange Española Tradicionalista $y$ de las Juntas de Ofensiva Nacionalsindicalista - Spanish Traditionalist Falange and Council of the National-Syndicalist Offensive). It should be stressed that the creation of the School was the product of two tendencies. The first was undoubtedly the already mentioned tendency of the regime to control information activity and to subordinate it to the ideology of the state, and the second was the desire to professionalise the journalistic profession. It was explicitly formulated by the founders of the School, including Juan Aparicio and Bartolomé Mostaz, who before the civil war had worked at the journalism school of the Catholic magazine El Debate, which became a model for the subsequent training of journalists. ${ }^{8}$

Formally, the School was under the authority of the Undersecretariat for People's Education, which was an agency of Falanga until 1945. From July 1945, competences in press matters - including the management of the School - were transferred to the Ministry of National Education, while from 1951 onwards, it was subordinated to the Ministry of Information and Tourism until the end of its functioning. The strict subordination of the administration meant that the authorities had complete freedom to appoint the professors teaching at the School and its staff. There was no doubt that both the academic staff and the students were subject to the control and guidelines of the Ministry officials. The decree of 29 July 1939 already obliged professors to subject their teaching to dogma, morality and canon law. ${ }^{9}$ Juan Aparicio, as the first director of the school, additionally required the staff to take the following oath: 'we swear before God, Spain and its Commander to serve the unity, greatness and freedom of the homeland, faithfully and with respect for the principles of the NationalSyndicalist State, placing ourselves at the service of the School of Journalism so that future promotions of Spanish journalists may uphold the founding spirit of the Falanga. ${ }^{10}$ The ideological formation of new cadres was to be achieved

${ }^{8}$ A. Tapia López, La enseñanza de la documentación en la escuela de periodismo de "El Debate". Antecedentes y evolución posterior (1889-1971), "Documentación de las Ciencias de la Información" 24 (2001), p. 223.

A. Tapia López, Las primeras enseñanzas de documentación en periodismo, "Documentación de las Ciencias de la Información” 24 (2001), p. 233.

${ }^{10}$ J. J. Videla Rodríquez, La formación de los periodistas en España: perspectiva histórica y propuestas de futuro, Madryt 2002, p. 147. 
not only through the appropriate attitude of the lecturers, but also through the educational programmes.

In the first period (1941-1951), the training covered two years and was supplemented by weekly conferences and journalistic internships during the summer holidays. The programme included subjects that could be divided into three blocks: one included classes with a strong ideological component, such as the life and doctrine of national syndicalism or national-syndicalist politics. Another block concerned general education, containing compendiums on culture, history or law (political science, geopolitics, modern history, philosophy, national economy, religious culture, history of literature, history of journalism and press legislation). The last block consisted of typically "technical" subjects, related to the practical side of the journalistic profession (literary editing, information and reportage, production of information, documentation). ${ }^{11}$ Since 1945 , the study plan has changed due to the development of technology and knowledge necessary to practice as a journalist. Thus, subjects such as graphic journalism and radio theory were introduced into the curriculum ${ }^{12}$. The ideological component in the teaching of journalists was also gradually reduced and more emphasis was placed on general education and practical subjects. ${ }^{13}$

The academic year 1951/1952 saw a significant change in the School's curriculum, extending the studies to three years. During the first two years, students acquired general knowledge of culture, history and literature as well as technical skills. The final year, however, was devoted to specialisation classes (press, illustration, radio, television). At the end of the course, the student could obtain the professional title of journalist, radio journalist or graphic journalist. ${ }^{14}$ From 1953, the school was defined as an "academic centre for the study of journalism", under the authority of the General Directorate of the Press. Since 1952, it was also been possible to gain a qualification in journalism in Barcelona, where the School had opened a branch. Initially, this school followed the same study programme as in Madrid, where students completed their final third year. It was

' J. J. Videla Rodríquez, La formación de los periodistas en España: perspectiva histórica $y$ propuestas de futuro, Madryt 2002, pp. 148-149.

12 A. Tapia López, Las primeras enseñanzas, p. 234.

${ }^{13}$ At the end of the Second World War, the influence of the Falanga in the government was weakened, and this also applied to the department responsible for education and the press. After 1945 , these areas came under the control of Catholic integrationists, who took care to remove any content associated with fascism from the curricula.

${ }^{14}$ A. Tapia López, Las primeras enseñanzas, p. 235. 
not until 1968 that the branch was granted autonomy, becoming the National School of Journalism of Barcelona. ${ }^{15}$

In addition to their studies, students had other responsibilities. Manuel Fernández Areal, a graduate of the school, recalled how difficult it was for him to endure the rigours introduced by Juan Aparicio, the director at the time (who was also Director General of the Press). According to Areal's account, once a month the students were obliged to attend the so-called 'editorial coffee meetings', accompanied by the director. The meetings were held at the Jaime Balmes Press Club belonging to the Ministry of Information. However, in spite of the encouraging name, they mainly served to pass on instructions, warnings and the public condemnation of unruly students by the school's director. ${ }^{16}$ The "manual control" of both the press and the functioning of the school described in the memoirs only eased in 1957, with the arrival of the more liberal Juan Beneyto as headmaster.

Within the same year the study plan changed significantly. The development of information technology gradually replaced traditional printing techniques with modern graphics, and television became an important source of information alongside radio. Some subjects (such as National Syndical Theory) were eliminated from the curriculum, while new ones appeared (e.g. advertising). ${ }^{17}$ These changes significantly improved the quality of education and professionalised the journalistic profession. Thanks to Juan Beneyto the significant reduction of the ideological component in the study programme and the gradual adaptation to modern standards in the training of journalists occurred.

The last significant change in the programme took place in 1967, when the study programme was extended to 4 years. Bartolome Mostaza, director of the school since 1964, planned to transform the institution into a College of Information Sciences. In the meantime, while the reorganisation of the study plans was dealt with, a decision was being reached at the same time, through a 1967 decree that the professional title of journalist would be equivalent to a university degree. ${ }^{18}$ According to the ordinance, the number of subjects was increased to 36 , and studies were to be concluded with a professional exam, the passing

${ }^{15}$ A. Tapia López, Las primeras enseñanzas, p. 235.

${ }^{16}$ M. Fernández Areal, Consejo de guerra. Los riesgos del Periodismo bajo Franco, Pontevedra 1997, pp. 62-65.

\footnotetext{
${ }^{17}$ J. J. Videla Rodríquez, La formación de los periodistas en España, p. 151.
}

${ }^{18}$ J. J. Videla Rodríquez, La formación de los periodistas en España, p. 153. 
of which was a prerequisite for admission to the journalistic profession. The study plan was created taking into account the opinions of the journalistic and scientific community, as well as global trends in the field of education in this profession. The passing of the new Press Law in 1966, which abolished prior censorship and provided for a certain opening up of the state's information policy, was of great importance.

\section{The origins of the School of Journalism of the Catholic Church}

In 1960, the Catholic Church in Spain claimed the right to establish its own school of journalism, guaranteed by the Concordat between Spain and the Apostolic See. This came as no surprise in Spain, where the Catholic press had a long tradition of training future students of the profession, with its most famous pre-war school, El Debate, at the forefront. Since this unit became the model for the post-war system of training journalists, it is appropriate here to take a brief look at the history of both the daily newspaper El Debate and its school.

The Catholic daily El Debate was founded in 1910, and from 1911 it came under the leadership of Ángel Herrera Oria, a lawyer who devoted his career in public administration to the creation of a Catholic paper. Herrera Oria was also a Catholic clergyman, associated with the Catholic Association of Propagandists (Asociación Católica de Propagandistas - ACdP) ${ }^{19}$ Interestingly, this highly distinguished figure in the development of Spanish journalism had no journalistic experience at the time he took over as editor-in-chief. Herrera Oria later recalled that at that time he 'only had to deal with the press at breakfast time.20 Paradoxically, however, he soon became a forerunner of modern journalism, understanding the need to separate information from opinion and to remain independent and impartial. Studying the functioning of the press in Western Europe, he began to implement modern solutions in El Debate, which was the first daily to have separate news, sports and economic sections, specialising the journalists working there.

Given Herrera Oria's serious approach to the professionalisation of the journalism profession, it is not difficult to understand his zeal to create

${ }^{19}$ J. J. Malpica Ruiz, El proyecto periodístico de Ángel Herrera Oria. Origen e implantación de la Escuela de Periodismo de la Iglesia y su influencia en la enseñanza, Madryt 2020, p. 112.

${ }^{20}$ J. M. García Escudero, De Periodista a Cardenal, Madryt 1998, p. 52. 
a comprehensive model of journalism education that became a model for later initiatives to integrate journalism into higher education. It was modelled on the existing modern forms of education in the United States, where it was conducted at the university level. ${ }^{21}$ The school began its activities on 10 March 1926, initially offering three-month specialisation courses in journalism. In the following years, the study period was successively extended, reaching 5 years of training in 1932 and attracting many students to the profession. ${ }^{22}$

The successful development of El Debate journalism school was interrupted by the outbreak of the Civil War, as a result of which the printing works of the Catholic Publishing House were confiscated by the authorities of the Republic for the communist Mundo Obrero and the weekly Politica. ${ }^{23}$ Along with the newspaper, the school was also closed down, as it later turned out irrevocably. After the end of the civil war, the Catholic Publishing House found itself in serious trouble, as the Church did not agree to the inclusion of the associated press titles under state censorship. The daily El Debate fell a victim of the conflict between the regime and the Church hierarchy. It did not appear again after the war and neither the school under its auspices. They shared its fate. ${ }^{24}$ This, however, does not change the fact that during its 10 years of existence, 'almost all those who later meant something in Spanish journalism went through the school. ${ }^{25}$ Its graduates represented the whole spectrum of ideologies, such as the anarchist Jacinto Toryho, the Falangist Dionisio Ridruejo or the aristocrat Luis Escobar y Kirkpatrik. ${ }^{26}$

\section{The Creation and Activities of the School of Journalism of the Catholic Church}

At the end of the 1950s, the changing political climate allowed the state's monopoly on the training of journalists to be broken. This was facilitated by the strong position of the Catholic Church, which, with its authority legitimised the

\footnotetext{
${ }^{21}$ A. Tapia López, La enseñanza de la documentación, p. 223.

${ }^{22}$ J. J. Malpica Ruiz, El proyecto periodístico, p. 113.

${ }^{23}$ J. J. Malpica Ruiz, El proyecto periodístico, p. 148.

${ }^{24}$ J. F. Fuentes, J. F. Sebastian, Historia del periodismo español, Madryt 1997, pp. 253-256.

${ }^{25}$ J. J. Malpica Ruiz, El proyecto periodístico, p. 130.

${ }^{26}$ J. J. Malpica Ruiz, El proyecto periodístico, p. 130.
} 
regime of General Franco, at the same time gaining significant influence on the way power was exercised, as well as a certain autonomy in terms of the social media subordinate to the Church. ${ }^{27}$ The press connected with the Church, affiliated to the National Council of the Catholic Press (Junta Nacional de Prensa Católica), used its own news agency and the Church Information and Statistics Office (OGIEI) created by the Spanish Episcopate. ${ }^{28}$ The creation of a school seemed to be the natural course and it actually happened by Decree of 7 September $1960 .{ }^{29}$

According to this law, the Episcopal Commission for Press and Information became the entity responsible for the organisation and management of the school, and its competences included issues such as the establishment of the training system, the internal organisation and staffing structure. The Commission entrusted the mission of establishing the school to Angel Herrera Oria, who thus re-organised the training of journalists after almost 25 years. Herrera Oria fulfilled his task and in November 1960 the school launched its activities in Madrid. Nicolás González Ruiz was appointed its director and the staff included many graduates of El Debate School. ${ }^{30}$ This climate of a certain continuity was characteristic of the functioning of the School of the Catholic Church, both at the level of the underlying idea and of the lecturers employed.

The school, in accordance with its religious profile, had the task of educating journalists capable of forming public opinion in accordance with Christian principles. In order to achieve this goal, future adepts of the profession had to, on the one hand, gain an excellent knowledge of the functioning of modern means of social communication, i.e. the press, radio and television, and, on the other, acquire the ability to select and appropriately interpret facts communicated to the public. Since, according to the decree, graduates of the school could

${ }^{27}$ J. Domke, Education, Fascism, and the Catholic Church in Franco's Spain, Zweibrücken 2011; M. Griera, The Education Battle: The Role of the Catholic Church in the Spanish Education System, "International Handbook of Catholic Education" 2007, pp. 291-310; C. Flecha Garcia, Education in Spain: Close-up of Its History in the 20th Century, "Analytical Reports in International Education" Vol. 4. No. 1 (2011), pp. 17-42.

${ }^{28}$ J. Terron Montero, La prensa en España durante el regimen de Franco, Madryt 1981, p. 117.

${ }^{29}$ Decreto 1784/60 (Ministerio de Informacion y Turismo) de 7 de septiembre, sobre convalidacion de los estudios cursados en la Escuela de Periodismo de la Jerarquia eclesiastica española, B.O.E. num. 230 de 24 septiembre p. 13359.

${ }^{30}$ A. Tapia López, Las primeras enseñanzas, p. 245. 
only work as journalists in media subordinate to the Church, the possibility of working in other social media required formal recognition of the title.

Thus, the curriculum had to be properly coordinated with that of the State School of Journalism, in order to enable the graduates to successfully pass the examinations confirming their skills. The Decree of 7 September 1960 and the Decree of 8 September 1962 were the legal basis for these examinations. According to them the recognition of the studies pursued at the Church School of Journalism and the issuance of the degree required the passing of oral, written and practical examinations covering the material pursued at the State School of Journalism. ${ }^{31}$ As a result of this requirement, the programmes of study had to coincide if they were to lead to professional qualifications.

Nevertheless, the School did not have to limit its curriculum to vocational subjects (reportage, journalistic genres, typography, radio journalism, television journalism, etc.), extending Catholic education, with particular emphasis on the social doctrine of the Catholic Church or subjects included in the canon of general education (economics, law or sociology). ${ }^{32}$

Candidates for the studies were subject to a strict selection process. In the first stage of recruitment, they had to present a curriculum vitae and justify their wish to study at the School and to practice journalism. On this basis, a preliminary selection was made, after which they had to take a written and oral exam. The offer of the School was met with great interest by students of journalism, among whom were also those who did not get into the State School of Journalism, or for ideological reasons did not want to study there. ${ }^{33}$ This is probably why, over time, a certain spirit of contestation towards the surrounding reality emerged within the walls of the school, the most striking evidence of which can be found in the fates of many of the school's graduates, who actively supported the political opposition in subsequent years.

The change in the curriculum and the extension of study to 4 years in the National School of Journalism resulted in similar changes in the Catholic Church School. The number of subjects was increased to 39 , of which 18 were vocational

${ }^{31}$ Of particular importance was Article 2 of the aforementioned Decree, according to which it is the university authorities that influence the staffing structure, organisation and study plan. See Decreto 2296/62 de 8 de septiembre en Boletín Oficial del Estado, 14 de septiembre de 1962, p. 13048.

${ }^{32}$ Decreto 2296/62 de 8 de septiembre en Boletín Oficial del Estado, 14 de septiembre de 1962, p. 13048.

${ }^{33}$ J. J. Videla Rodríquez, La formación de los periodistas en España, p. 158. 
subjects including internships, 17 were cultural subjects, of which 4 were devoted to the thought of the Catholic Church, and 2 were information sciences. ${ }^{34}$ The students also studied two foreign languages over a period of four years. The School of the Catholic Church also offered journalism degrees to university graduates who wished to obtain this qualification. In 1968-69, courses were run that enabled students to obtain a degree for a few months that normally required four years of study. The possibility of gaining professional qualifications in this way illustrates a certain opening up of access to the profession of journalism, which was evident throughout the 196os and which found its full expression when the relevant departments were created at the university. These years also saw a certain decentralisation, i.e. the possibility of studying journalism outside Madrid. From 1959, it was possible to study in Valencia, at the School of Journalism of the Catholic Action, but national recognition of the degrees obtained only happened when the school came under the authority of the diocesan bishop as a branch of the School of the Catholic Church in Madrid (1965). ${ }^{36}$ Barcelona also gained a suitable training centre when Bishop Gregorio Modrego Casasús established the School of Journalism of the Catholic Church in Barcelona by decree of 22 November $1964 .{ }^{37}$ Decentralisation and the gradual liberalisation fostered by the new Press Law of 1966 opened up the possibility of diversification in the training of journalists, heading towards transferring teaching within the walls of the University.

\section{Summary}

The preparation for the journalistic profession under an authoritarian system usually becomes a matter of particular interest for the authorities. This was no different in the case of Francoist's Spain, where the Press Law of 1938 laid down detailed conditions for practising the profession. The only way to practise the profession was through the School of Journalism, which was subordinated

${ }^{34}$ J. J. Videla Rodríquez, La formación de los periodistas en España, p. 158.

${ }^{35}$ M. Vigil y Vásquez, El periodismo enseñado. De la escuela de El Debate a Ciencias de la Informacion, Barcelona 1987, pp. 75-82.

${ }^{36}$ M. Vigil y Vásquez, El periodismo enseñado. De la escuela de El Debate a Ciencias de la Informacion, Barcelona 1987, pp. 75-82.

${ }^{37}$ M. Vigil y Vásquez, El periodismo enseñado. De la escuela de El Debate a Ciencias de la Informacion, Barcelona 1987, pp. 75-82. 
to the state, where the political criteria for selecting candidates and the appropriate ideological formation were supposed to prepare cadres ready to obediently carry out the regime's information policy. This objective was partly achieved, especially in the early years of Francoism. However, incidentally, subjecting the training of journalists to scrutiny has contributed significantly to the professionalization of this profession.

The successful initiative to establish the Catholic Church's School of Journalism marked the beginning of the regime's gradual relinquishment of total control over the training of journalists in favour of limited pluralism. This was one of the elements of the progressive liberalisation of the Spanish political system, which in the mid-1950s was moving away from economic autarky and a policy of isolation towards greater international cooperation. ${ }^{38}$ The competition between schools (although still slight at that time) contributed to an increase in the quality of education. The emphasis on the completion of general education or the design of curricula taking into account the development of information technology made it possible to equip students with competences required in the labour market, which previously could only be obtained to a greater or lesser extent in practice.

It must be stressed that the School of Journalism of the Catholic Church, like the State School of Journalism, met the requirements for professional training in the field of journalism, which was reflected in the curricula that were developed in subsequent years. In fact, the curricula overlapped to a great extent, thanks to which graduates of the School of the Catholic Church gained the necessary preparation to successfully pass the state examination, which opened the way to work in all media in the country. At the same time, throughout its existence, the School of the Catholic Church has maintained its distinctiveness, remaining faithful to the principles set out by Herrera Oria back in the days of $E l$ Debate School. The school's founder attached great importance to the general education of the students of journalism, hence subjects like history, philosophy, economics, law and sociology featured prominently in the curriculum. Given the Catholic profile of the school, the curriculum also included subjects such as the social doctrine of the Catholic Church and canon law, which deepened the students' religious formation. On the other hand, great emphasis was placed

${ }^{38}$ J. Jaroszyk, Wolność słowa a demokracja. Hiszpański system prasowy w latach 1975-2005, Poznań 2020, pp. 45-52. 
on the study of foreign languages (which was unique in Spain at that time), thus completing the comprehensive education of future journalists.

A fundamental change in the education of journalists came with its integration into the structure of the University. This became possible only after the enactment of the Press Law of 1966, which sealed the implementation of a profound reform and finally freed the education of journalists from the influence of the regime. The Faculties of Information Sciences, created from 1971 onwards, made university-level education possible, in line with the trend and standards developing in the world. In the following years, various universities in Spain opened Departments of Information Sciences, and university education in this profession became the standard. In the case of the School of Journalism of the Catholic Church, which was so important in breaking the state's monopoly on the training of journalists and was eventually closed down by law in 1975, it was possible, after much wrangling, to set up a Faculty of Information Sciences within the Pontifical University of Salamanca, thus continuing the mission of training journalists begun in 1911 at the school of El Debate.

\section{Bibliography}

\section{Normative Acts}

Orden de 24 de mayo (Ministerio de la Gobernacion) sobre depuración de la conducta de periodistas en relación con el Movimiento Nacional, B.O.E. num. 145 de 25 de mayo 1939, p. 2822.

Decreto 2296/62 de 8 de septiembre, sobre convalidacion de los estudios cursados en el Instituto de Periodismo de la Iglesia en Pamplona, B.O.E. de 14 de septiembre de 1962, p. 13048.

Decreto 1784/60 (Ministerio de Informacion y Turismo) de 7 de septiembre, sobre convalidacion de los estudios cursados en la Escuela de Periodismo de la Jerarquia eclesiastica española, B.O.E. num. 230 de 24 septiembre de 1962, p. 13359.

Ley 14/1970, de 4 de Agosto, General de Educación y Financiamiento de la Reforma Educativa, B.O.E nr 187, de 6 de Agosto de 1970, p. 12525-12546.

\section{Studies}

Cruz Seoane M., Dolorez Sainz M., Cuatro siglos de periodismo en España. De los avisos a los periódicos digitales, Madryt 2015.

Domke J., Education, Fascism, and the Catholic Church in Franco's Spain, Zweibrücken 2011. Dueñas G., La ley de prensa de Manuel Fraga, Madryt 1969. 
Escobar de la Serna L., Manual de derecho de la informacion, Madryt 1997.

Escobar Roca G., El Estatuto de los Periodistas, Madryt 2002.

Fernández Areal M., Consejo de guerra. Los riesgos del Periodismo bajo Franco, Pontevedra 1997.

Flecha Garcia C., Education in Spain: Close-up of Its History in the 20th Century, "Analytical Reports in International Education” Vol. 4. No. 1 (2011), pp. 17-42.

Fuentes J. F., Fernandez Sebastian J., Historia del periodismo espanol, Madryt 1997.

Griera M., The Education Battle: The Role of the Catholic Church in the Spanish Education System, "International Handbook of Catholic Education” 2007, pp. 291-310.

Jaroszyk J., Wolność słowa a demokracja. Hiszpański system prasowy w latach 1975-2005, Poznań 2020.

Sanchez Aranda J. J., Barrera C., Historia del periodismo espanol, Pampeluna 1992.

Malpica Ruiz J. J., El proyecto periodístico de Ángel Herrera Oria. Origen e implantación de la Escuela de Periodismo de la Iglesia y su influencia en la enseñanza, Madryt 2020.

Tapia López A., La enseñanza de la documentación en la escuela de periodismo de "El Debate". Antecedentes y evolución posterior (1889-1971), "Documentación de las Ciencias de la Información” 24 (2001), pp. 213-229.

Tapia López A., Las primeras enseñanzas de documentación en periodismo, "Documentación de las Ciencias de la Información” 24 (2001), pp. 231-253.

Terron Montero J., La prensa en España durante el regimen de Franco. Un intento de analisis politico, Madryt 1981.

Videla Rodríquez J.J., La formación de los periodistas en España: perspectiva histórica y propuestas de futuro, Madryt 2002.

Vigil y Vásquez M., El periodismo enseñado. De la escuela de El Debate a Ciencias de la Informacion, Barcelona 1987. 
